\title{
Insecticide resistance in Anopheles arabiensis populations from Dakar and its suburbs: role of target site and metabolic resistance mechanisms
}

\author{
A. Kane Dia ${ }^{1 * \dagger}$, O. Kalsom Guèye ${ }^{1 \dagger}$, E. Amadou Niang ${ }^{1,2 \dagger}$, S. Mocote Diédhiou ${ }^{1}$, M. Demba Sy ${ }^{1}$, \\ Abdoulaye Konaté ${ }^{1}$, Badara Samb ${ }^{1}$, Abdoulaye Diop ${ }^{3}$, Lassana Konaté ${ }^{1}$ and Ousmane Faye ${ }^{1}$
}

\begin{abstract}
Background: Urban malaria is an increasing concern in most of the sub-Saharan Africa countries. In Dakar, the capital city of Senegal, the malaria epidemiology has been complicated by recurrent flooding since 2005. The main vector control measure for malaria prevention in Dakar is the community use of long-lasting insecticide-treated nets. However, the increase of insecticide resistance reported in this area needs to be better understood for suitable resistance management. This study reports the situation of insecticide resistance and underlying mechanisms in Anopheles arabiensis populations from Dakar and its suburbs.

Results: All the populations tested showed resistance to almost all insecticides except organophosphates families, which remain the only lethal molecules. Piperonil butoxide (PBO) and ethacrinic acid (EA) the two synergists used, have respectively and significantly restored the susceptibility to DDT and permethrin of Anopheles population. Molecular identification of specimens revealed the presence of An. arabiensis only. Kdr genotyping showed the presence of the L1014F mutation ( $k d r$-West) as well as L1014S ( $k d r$-East). This L1014S mutation was found at very high frequencies (89.53\%) in almost all districts surveyed, and in association with the L1014F (10.24\%).

Conclusion: Results showed the contribution of both target-site and metabolic mechanisms in conferring pyrethroid resistance to An. arabiensis from the flooded areas of Dakar suburbs. These data, although preliminary, stress the need for close monitoring of the urban An. arabiensis populations for a suitable insecticide resistance management system to preserve core insecticide-based vector control tools in this flooded area.
\end{abstract}

Keywords: Anopheles arabiensis, Dakar, L1014S, L1014F, Insecticide resistance, Metabolic, Synergist, WHO, CDC bottle

\section{Background}

Malaria is still a major public health emergency across the sub-Saharan Africa [1]. The Senegalese Malaria Control Programme has made unprecedented progresses against the disease, and is now targeting malaria pre-elimination/elimination in eligible areas. However,

\footnotetext{
*Correspondence: milakd1@hotmail.com

${ }^{\dagger}$ A. Kane Dia, O. Kalsom Guèye and E. Amadou Niang contributed equally to this work

${ }^{1}$ Laboratoire d'Ecologie Vectorielle et Parasitaire, Université Cheikh Anta Diop, Dakar, Senegal

Full list of author information is available at the end of the article
}

despite the encouraging results, malaria stills endemic in the most parts of the country, including Dakar and its suburbs where the epidemiology of the disease has been locally complicated by recurrent flooding since 2005 . Indeed, floods have created suitable conditions for the persistence of Anopheles arabiensis larval habitats yearround [2-6]. In this context, the subsequent upsurge of vector populations' densities increases the risk of malaria transmission in such a high-density of non-immune population. Moreover, the above-mentioned successes were made possible by scaling-up effective malaria control interventions, including the two core malaria vectors 
control tools: long-lasting insecticide-treated nets (LLIN) and indoor residual spraying (IRS). Indeed, across the sub-Saharan Africa, the proportion of the population at risk sleeping under an insecticide-treated net or protected by IRS increased from $37 \%$ in 2010 to $57 \%$ in 2015 [7].

In Senegal, as part of the malaria control effort with the U.S. President's Malaria Initiative (PMI), the IRS programme has been introduced then scaled-up in different eco-epidemiological areas of the country $[8,9]$. High reliance on these insecticide-based interventions has subjected the targeted vectors populations to an increasing insecticide pressure for the selection of the resistance phenotypes. The spread of the resistance to the main insecticide classes approved by the World Health Organization (WHO) for use in public health threatens the success of the pre-elimination and elimination programmes in Senegal [8]. In areas such as the western coastal areas, where the impact of climate change is most felt, the conjunction of climate hazards and insecticide resistance will increase the risk and the heterogeneity of malaria epidemiology [10]. Therefore, monitoring insecticide resistance in the main urban malaria vector, An. arabiensis, is essential for planning and implementing an effective vector control programme in this area.

This study was undertaken to characterize insecticide resistance and underlying mechanisms among the urban An. arabiensis populations across the flooded areas of the Dakar suburbs, the capital of Senegal.

\section{Methods}

\section{Study area}

The study was conducted during three successive years 2013, 2014 and 2015. Ten sites of Dakar and its suburbs (Pikine and Guediawaye) were surveyed during the 2013 rainy season and 2014 dry season for the first round of the study, then during the 2015 rainy season a second round was conducted only in the suburbs area of the administrative department of Pikine and Guediawaye (Fig. 1 and Table 1). The study area, located in a specific eco-geographical zone known as "Niayes", is characterized by interdunal depressions, which are flooded during the rainy season. The region belongs to the sudano-sahelian domain with a rainy season from July to October and

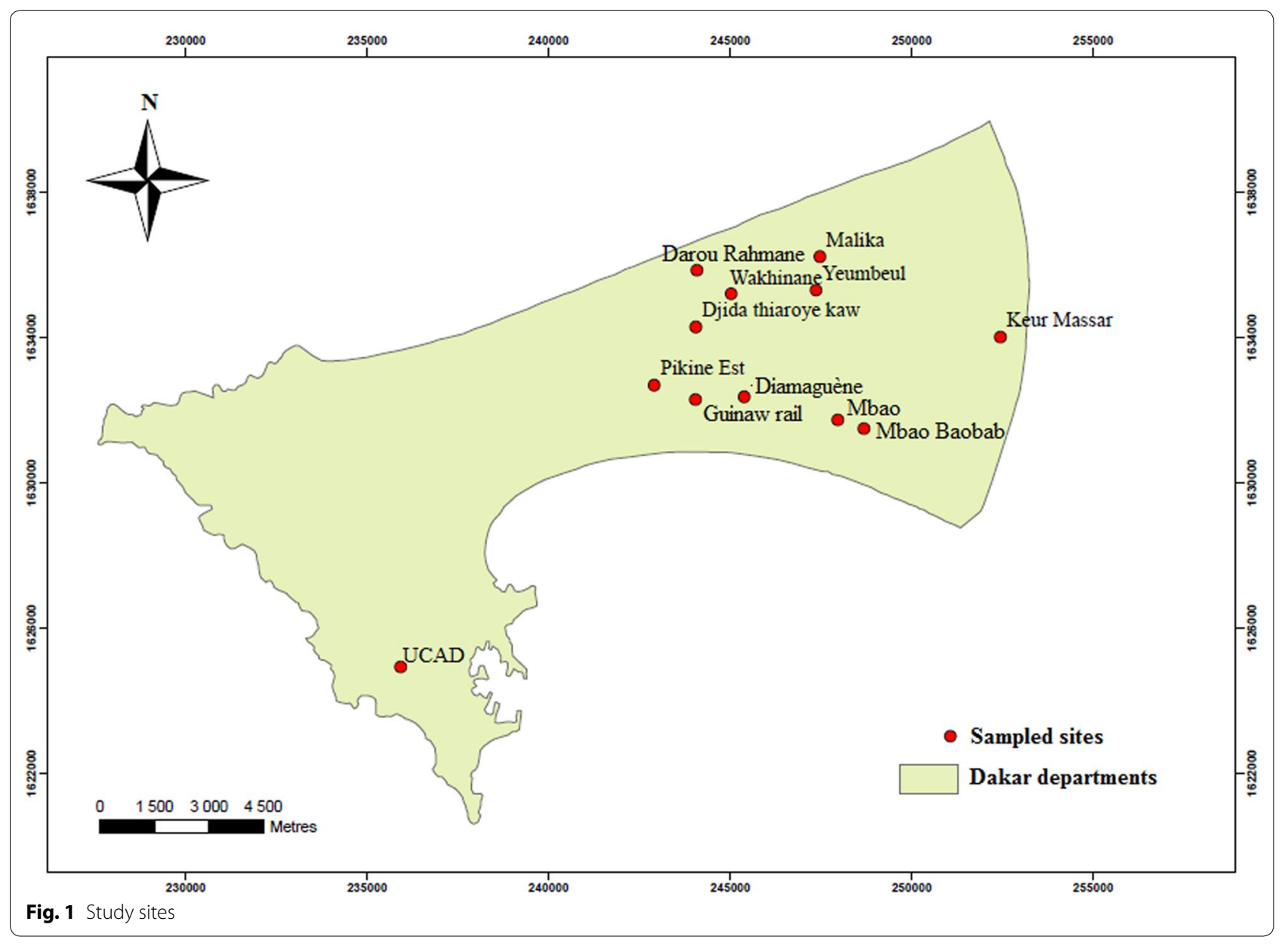


Table 1 Insecticide molecules and diagnostic concentrations used for each study locality and season

\begin{tabular}{|c|c|c|c|c|}
\hline \multirow[t]{2}{*}{ Districts } & \multirow{2}{*}{$\begin{array}{l}\text { RS } 2013 \\
\text { WHO papers }\end{array}$} & \multirow{2}{*}{$\begin{array}{l}\text { DS } 2014 \\
\text { WHO papers }\end{array}$} & \multicolumn{2}{|l|}{ RS 2015} \\
\hline & & & WHO papers & CDC-bottle \\
\hline Dakar centre & $\begin{array}{l}\text { Bendiocarb } 0.1 \% \\
\text { Pirimiphos methyl } 0.25 \%\end{array}$ & - & - & - \\
\hline Mbao & $\begin{array}{l}\text { DDT } 4 \% \\
\text { Deltamethrine } 0.05 \% \\
\text { Alphacypermethrin } 0.05 \% \\
\text { Bendiocarb 0.1\% } \\
\text { Pirimiphos methyl } 0.25 \%\end{array}$ & $\begin{array}{l}\text { DDT 4\% } \\
\text { Permethrin } 0.75 \% \\
\text { Deltamethrin } 0.05 \% \\
\text { Bendiocarb } 0.1 \% \\
\text { Malathion } 5 \% \\
\text { Pirimiphos methyl } 0.25 \%\end{array}$ & - & - \\
\hline Pikine & $\begin{array}{l}\text { Dieldrin } 4 \% \\
\text { Permethrin } 0.75 \%\end{array}$ & - & $\begin{array}{l}\text { DDT 4\% } \\
\text { Dieldrin 4\% } \\
\text { Permethrin 0.75\% } \\
\text { Deltamethrin 0.05\% } \\
\text { Alphacypermethrin 0.05\% } \\
\text { Cyfluthrin 0.15\% } \\
\text { Lambda-cyhalothrin 0.05\% } \\
\text { Bendiocarb 0.1\% } \\
\text { Malathion 5\% } \\
\text { Pirimiphos methyl 0.25\% } \\
\text { Fenitrothion 1\% }\end{array}$ & $\begin{array}{l}\text { DDT 4\% } \\
\text { Permethrin 0.75\% } \\
\text { Deltamethrin } 0.05 \% \\
\text { Bendiocarb } 0.1 \% \\
\text { Pirimiphos methyl } 0.25 \%\end{array}$ \\
\hline Keur Massar & $\begin{array}{l}\text { DDT 4\% } \\
\text { Bendiocarb 0.1\% } \\
\text { Malathion 5\% } \\
\text { Fenitrothion 1\% }\end{array}$ & $\begin{array}{l}\text { DDT 4\% } \\
\text { Permethrin } 0.75 \% \\
\text { Deltamethrin } 0.05 \% \\
\text { Bendiocarb } 0.1 \% \\
\text { Malathion } 5 \% \\
\text { Pirimiphos methyl } 0.25 \%\end{array}$ & - & - \\
\hline Guediawaye & Deltamethrin $0.05 \%$ & - & $\begin{array}{l}\text { DDT 4\% } \\
\text { Dieldrin 4\% } \\
\text { Permethrin 0.75\% } \\
\text { Deltamethrin 0.05\% } \\
\text { Alphacypermethrin 0.05\% } \\
\text { Cyfluthrin 0.15\% } \\
\text { Lambda-cyhalothrin 0.05\% } \\
\text { Bendiocarb 0.1\% } \\
\text { Malathion 5\% } \\
\text { Pirimiphos methyl 0.25\% } \\
\text { Fenitrothion 1\% }\end{array}$ & $\begin{array}{l}\text { DDT 4\% } \\
\text { Permethrin 0.75\% } \\
\text { Deltamethrin } 0.05 \% \\
\text { Bendiocarb } 0.1 \% \\
\text { Pirimiphos methyl } 0.25 \%\end{array}$ \\
\hline
\end{tabular}

a dry season from November to June. The region average temperatures ranging from 24 to $30{ }^{\circ} \mathrm{C}$ during the rainy season and from 19 to $25{ }^{\circ} \mathrm{C}$ during the dry season. For the year 2013, 2014 and 2015 the annual rainfall was 567, 161 and $635 \mathrm{~mm}$, respectively [11]. Dakar is the most populated Senegalese region with a density of 5404 inhabitants per $\mathrm{km}^{2}$ [12].

\section{Sampling and rearing mosquito larvae}

Anopheles larvae and pupae were collected from natural breeding sites within and around the study sites. Upon collection, they were kept in separate labelled buckets, transported to the insectary and maintained under optimal rearing condition at a relative humidity of $75 \pm 5 \%$ and a temperature of $28 \pm 2{ }^{\circ} \mathrm{C}$ as described in the MR4 manual for mosquitoes rearing [13].

\section{Insecticide susceptibility tests}

In 2013 and 2014, bioassays were carried out using only the WHO test kits for adult mosquitoes [14]. While, for the 2015 study year, populations were tested using both the WHO standard test and the CDC Bottle test $[14,15]$. The WHO insecticide-impregnated papers were provided by The Vector Control Research Unit, School of Biological Sciences (Universiti Sains Malaysia), a WHO Collaborating Centre, while insecticide for the bottle test were provided by the Centers for Disease Control and Prevention (CDC), Atlanta, USA.

Non-blood-fed, 3-5 days old adults females of Anopheles gambiae sensu lato (s.l.) were exposed to diagnostic concentrations of insecticides for the required diagnostic time for each molecule [14]. For each insecticide, four tests and two control replicates of 25 mosquitoes were used for each test round. 


\section{Detection of metabolic resistance mechanisms}

To assess the presence of the metabolic resistance mechanisms, 3-5 days old of non-blood-fed An. gambiae s.l. adult females were pre-exposed to the piperonyl butoxide (PBO) or ethacrynic acid (EA) prior to be exposed to insecticides [15].

\section{Species identification and kdr molecular genotyping}

Genomic DNA was extracted from individual mosquitoes as described by CTAB method and the member of the An. gambiae complex were identified as described by Wilkins et al. [16]. The $k d r$ mutations molecular genotyping was performed as described in Huynh et al. [17].

\section{Data analysis}

WHO susceptibility and CDC bottle tests were used to monitor resistance to insecticides belonging to the four WHO-approved chemical classes over the study period. The $k d r$ allele frequency was estimated for each site and period of collection as the proportion of specimens with the L1014F and/or L1014S $k d r$ alleles. All statistical analyses were performed using $\mathrm{R}$ soft-ware (version 3.3.2) [18].

\section{Results}

\section{Species identification and susceptibility to insecticide}

Molecular identification revealed the exclusive presence of $A n$. arabiensis in all the study areas and sites. WHO susceptibility tests were performed on 1414; 1687 and 3316 An. arabiensis specimens, respectively in 2013, 2014 and 2015 (Table 1). Anopheles arabiensis populations were resistant to almost all insecticides, but generally fully susceptible to organophosphates.
In 2014, the studied population displayed pronounced resistance to pyrethroids and DDT, especially in Mbao during the rainy season where populations were fully resistant to the permethrin. Excepted for the dieldrin (organochlorine) and the cyfluthrin (pyrethroid) in Pikine, both $A n$. arabiensis populations in Guediawaye and Pikine were resistant to DDT and pyrethroids during the 2015 rainy season (Table 2 ).

All $A n$. arabiensis populations were resistant to the bendiocarb during the whole study period except in Yeumbeul (98.81\%) in 2013. Excepted Mbao Baobab and Pikine, where suspected resistance to Malathion was noticed in 2014; and for Guediawaye populations which were resistant to Fenitrothion during the 2015 rainy season, all the studied populations were fully susceptible to organophosphates (Table 3).

In 2015 the susceptibility tests were carried out for the permethrin, deltamethrin, DDT, pirimiphos-methyl and bendiocarb using the standard WHO-impregnated paper test as well as the CDC Bottle test. Both methods have shown that $A n$. arabiensis populations from Guediawaye and Pikine were resistant to DDT and pyrethroids (Tables 2, 3, 4). However, the results were different for the two remaining molecules; with both populations being fully susceptible to the pirimiphos-methyl but resistant to the bendiocarb using the impregnated paper test; while an opposite trend was recorded for the Bottle test.

\section{Resistance mechanisms}

The CDC Bottle test with synergists was used to assess the presence of the metabolic resistance mechanisms. Results indicate the involvement of metabolic resistance mechanisms via GST and CYP450 detoxification genes families. In Pikine, pre-exposure to PBO has significantly

Table 2 Twenty-four hours post-exposure mortality (\%) to pyrethroid (PYR) and organochlorine (OC) using the WHO impregnated papers

\begin{tabular}{|c|c|c|c|c|c|c|c|c|c|}
\hline & \multirow[t]{2}{*}{ Districts } & \multirow[t]{2}{*}{ Localities } & \multicolumn{2}{|l|}{ OC } & \multicolumn{5}{|l|}{ PYR } \\
\hline & & & DDT & Dieldrin & Permethrin & Deltamethrin & Alpha cypermethrin & Cyfluthrin & $\begin{array}{l}\text { Lambda } \\
\text { cyhalothrin }\end{array}$ \\
\hline \multirow[t]{5}{*}{ RS 2013} & Guediawaye & Wakhinane & - & - & - & $65(100)$ & - & - & - \\
\hline & Keur Massar & Keur Massar & $4(91)$ & - & - & - & - & - & - \\
\hline & Mbao & Mbao Baobab & $7(95)$ & - & - & $73(94)$ & - & - & - \\
\hline & & Diamaguene & - & - & - & - & $38(98)$ & - & - \\
\hline & Pikine & Pikine Est & - & $14(93)$ & $39(93)$ & - & - & - & - \\
\hline \multirow[t]{2}{*}{ DS 2014} & Keur Massar & Yeumbeul & $1(85)$ & - & $2(102)$ & $69(97)$ & - & - & - \\
\hline & Mbao & Mbao & $3(103)$ & - & $0(94)$ & $46(102)$ & - & - & - \\
\hline \multirow[t]{2}{*}{ RS 2015} & Guediawaye & Darou Rahmane & $0.98(102)$ & $31(124)$ & $3(102)$ & 47 (104) & 42.59 (108) & 31.69 (124) & $17(112)$ \\
\hline & Pikine & Guinaw Rails & $1(113)$ & $14(103)$ & $21.81(110)$ & $62(110)$ & $64.22(123)$ & $25.04(104)$ & $23(100)$ \\
\hline
\end{tabular}

$R S$ rainy season, $D S$ dry season

() Numbers between brackets indicate the total of specimens tested 
Table 3 Twenty-four hours post-exposure mortality (\%) to carbamate (CAR) and organophosphate (OP) using the WHO impregnated papers

\begin{tabular}{|c|c|c|c|c|c|c|}
\hline & \multirow[t]{2}{*}{ Districts } & \multirow[t]{2}{*}{ Localities } & \multirow{2}{*}{$\begin{array}{l}\text { CAR } \\
\text { Bendiocarb }\end{array}$} & \multicolumn{3}{|l|}{ OP } \\
\hline & & & & Pyrimiphos methyl & Malathion & Fenitrothion \\
\hline \multirow[t]{5}{*}{ RS 2013} & Dakar centre & UCAD & $2.99(93)^{\mathrm{a}}$ & $100(87)$ & - & - \\
\hline & Keur Massar & Yeumbeul & $98.81(93)$ & - & - & - \\
\hline & & Keur Massar & - & - & $100(96)$ & - \\
\hline & & Malika & - & - & - & $100(101)$ \\
\hline & Mbao & Mbao Baobab & $88(86)$ & $100(97)$ & - & - \\
\hline \multirow[t]{4}{*}{ DS 2014} & Keur Massar & Yeumbeul & $27.03(74)$ & $100(86)$ & $100(99)$ & - \\
\hline & Mbao & Mbao & $0.96(104)$ & - & - & - \\
\hline & & Mbao Baobab & - & - & $94(98)$ & - \\
\hline & & Djida Thiaroye & - & $100(91)$ & - & - \\
\hline \multirow[t]{2}{*}{ RS 2015} & Guediawaye & Darou Rahmane & $35.17(107)$ & $100(103)$ & $100(102)$ & $73.05(106)$ \\
\hline & Pikine & Guinaw Rails & $62(120)$ & $100(118)$ & $95(120)$ & $100(103)$ \\
\hline
\end{tabular}

$R S$ rainy season; $D S$ dry season

() Numbers between brackets indicate the total of specimens tested

a Corrected mortality corrected

Table 4 Post-exposure mortality (\%) to pyrethroid (PYR), organochlorine (OC), carbamate (CAR) and organophosphate (OP) using the CDC bottles test

\begin{tabular}{|c|c|c|c|c|c|c|}
\hline \multirow[t]{2}{*}{ Districts } & \multirow[t]{2}{*}{ Localities } & \multirow{2}{*}{$\begin{array}{l}\text { OC } \\
\text { DDT }\end{array}$} & \multicolumn{2}{|l|}{ PYR } & \multirow{2}{*}{$\begin{array}{l}\text { CAR } \\
\text { Bendiocarb }\end{array}$} & \multirow{2}{*}{$\begin{array}{l}\text { OP } \\
\text { Pirimiphos-methyl }\end{array}$} \\
\hline & & & Permethrin & Deltamethrin & & \\
\hline Guediawaye & Darou Rahmane & $1.98(101)$ & $86.66(105)$ & 93.45 (107) & $100(96)$ & $61.22(98)$ \\
\hline Pikine & Guinaw Rails & $36.19(105)$ & $87.12(101)$ & $83.01(106)$ & $100(106)$ & $55.66(106)$ \\
\hline
\end{tabular}

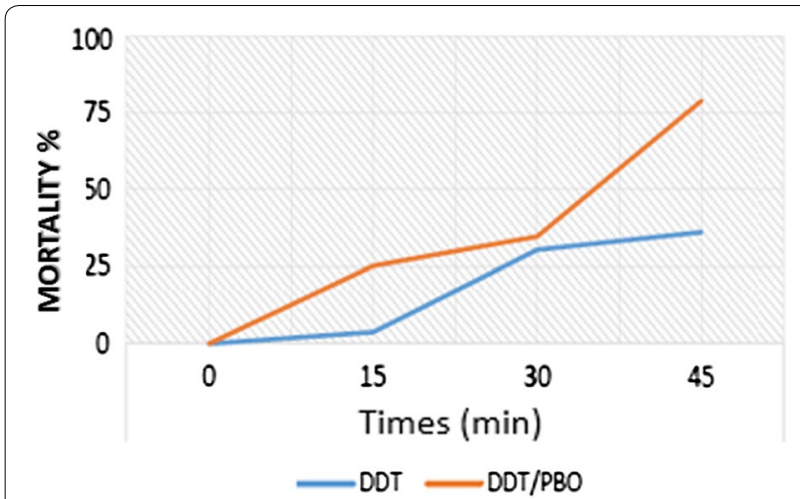

Fig. 2 Partial restauration of the susceptibility to DDT in resistant populations of Anopheles arabiensis after pre-exposure to PBO

restored the susceptibility of tested An. arabiensis populations to DDT with increased mortality from 36.19 to 78.95\%; while complete restoration of susceptibility to permethrin was noted (from 87.12 to $100 \%$ ) (Figs. 2 and 3). A 25 -fold (1.98 to $52.17 \%$ ) restoration of susceptibility to DDT was recorded for Guediawaye populations after pre-exposure to EA suggesting a GST-mediated metabolic resistance (Fig. 4).

The $k d r$ (L1014F and L1014S) mutations, conferring cross-resistance to DDT and pyrethroids, have been also investigated. Except in Djida Thiaroye Kaw where only the L1014S mutations was found, both mutations were present in all the study sites with respective frequencies of 10.24 and $89.53 \%$ for the West African (L1014F) and East African (L1014S) mutations. Notably, the East African mutations was significantly higher than the West African one $(p<0.05)$. Both mutations were identified either at homozygous or heterozygous resistant genotype varying between study sites. The homozygous L1014S resistant genotype was the most common genotype in all the surveyed sites with the highest frequency recorded in Mbao, while the less common genotype was the heterozygous $1014 \mathrm{~S} / 1014 \mathrm{~L}$ with the lowest accounted only for $1.56 \%$ of all the genotype in Pikine (Fig. 5).

\section{Discussion}

During this study, An. arabiensis was the sole member of the Gambiae complex encountered in all the surveyed sites. This confirms this species as the unique or 


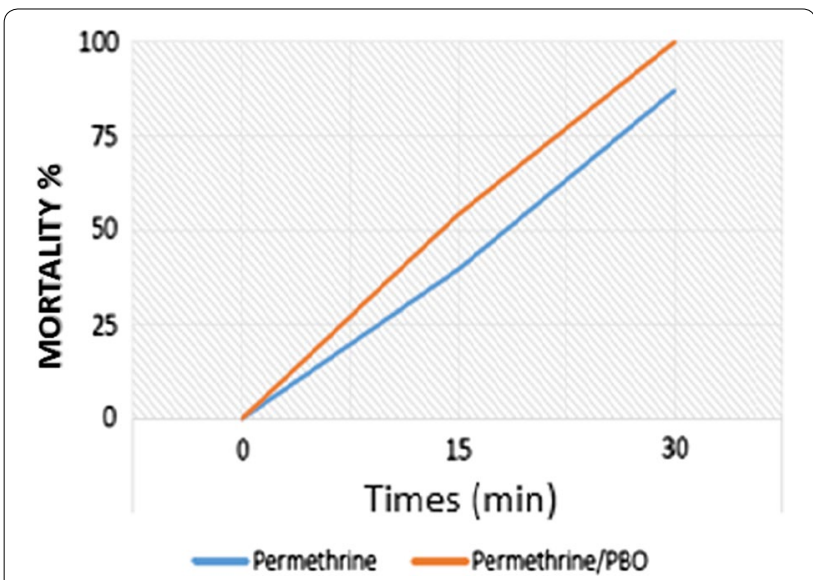

Fig. 3 Partial restauration of the susceptibility to permethrin in resistant populations of Anopheles arabiensis after pre-exposure to $\mathrm{PBO}$

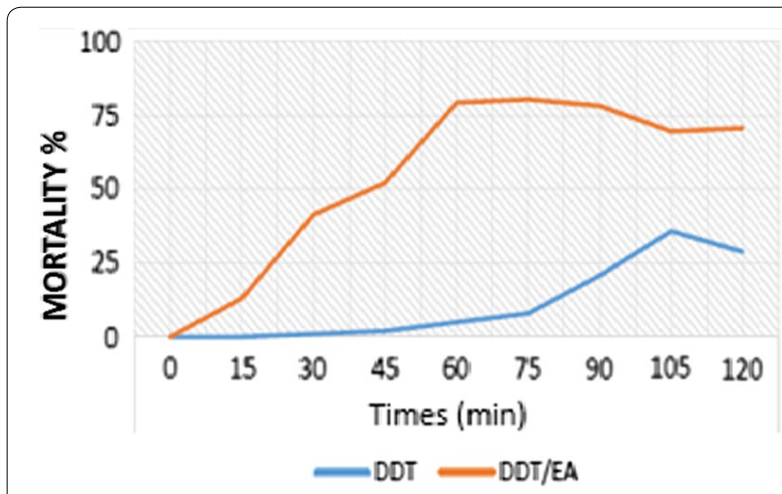

Fig. 4 Partial restauration of the susceptibility to DDT in resistant populations of Anopheles arabiensis after pre-exposure to EA

main representant of the Gambiae complex in Dakar [2, 5, 6, 19]. No specimen of Anopheles melas or Anopheles coluzzii, previously reported $[6,20]$ was found over the study period. During their study Gadiaga et al. [6] collected An. melas both at the larval and adult stages. Anopheles melas larvae were often collected in association with $A n$. arabiensis from a variate breeding sites located in Cafeteriat, Pikine and Zone A, in Dakar suburb. The absence of An. melas from the larval collection may be explained by the lower sampling effort compared to the previous study. A recent study carried-out in the same geographical area reported also only the presence of An. arabiensis in both larval and adult anopheline populations [2, 3].

Historically, An. arabiensis is considered as the main malaria vector in the Cap Vert Peninsula where it is found all the year-round [21, 22]. Robert et al. [21] attributed this to the presence of permanent larval habitats formed by the so-called "Ceane" gardening pits which served as breeding site, especially during the dry season. Gadiaga et al. [6] found significant difference in larval habitats conductivity between breeding sites containing both An. melas and An. arabiensis (5.03) and those exclusive for An. arabiensis (1.75), with the conductivity of the water being the highest when An. melas was present.

WHO susceptibility tests showed that An. arabiensis populations were resistant to three classes of insecticides, but susceptible to organophosphates. The pronounced resistance to pyrethroids in the study populations is consistent with the overall situation reported for malaria vectors to this chemical family across the sub-Saharan Africa [1].

The study populations were more susceptible to organophosphate compared to carbamate. Indeed, all $A n$. arabiensis populations were resistant to the bendiocarb except in Yeumbeul during the 2013 rainy season. Similar results were previously reported in the country including the study area [23]. This situation may be explained by an extensive use of insecticide for crops protection in the market gardening activities in the Niayes area [24, 25]. Moreover, Faye et al. [26] have previously reported a resistance of An. gambiae s.l. to DDT in the Niayes. The current cross-resistance of $A n$. arabiensis populations to pyrethroids and DDT may be an heritage of an extensive agricultural used of DDT in the past as hypothesized in Burkina Faso [27]. However, Padonou et al. [28] attributed it rather to the use of pyrethroids in public health.

Both the L1014F ( $k d r$-West or $k d r-w$ ) and the L1014S ( $k d r$-East or $k d r-e)$ mutations, the two target site mechanisms conferring a cross-resistance to DDT and pyrethroids were found in almost all the study sites. Previous studies have reported the presence of the L1014F mutation nationwide with variable frequencies across the country and between studies $[10,25]$. Indeed, the $k d r-w$ mutation was previously reported in the study area by Pagès et al. [20]; and, as shown here, its frequencies have increased since this first description. During this study, the $k d r-e$ mutation also found in study populations, was the most widespread and the most frequent $k d r$ allele. Therefore, more investigations are necessary to assess the contribution of each mutations to the resistance level of An. arabiensis across its distribution range. Soderlund and Knipple [29] have reported that the $k d r$-w mutation confers a highest resistance level, while the $k d r-e$ gives a selective advantage to the individual that carries it [30].

The $20 \%$ co-occurrence of the two mutations in An. arabiensis as observed here is similar to previous observations from several other sub-Saharan African countries, including Burkina Faso [31], Tanzania [32], Cameroon [33, 34], Gabon [35] and Uganda [36].

The absence of organophosphates-carbamates crossresistance suggests the absence of the ace- $1^{\mathrm{R}}$ mutation 


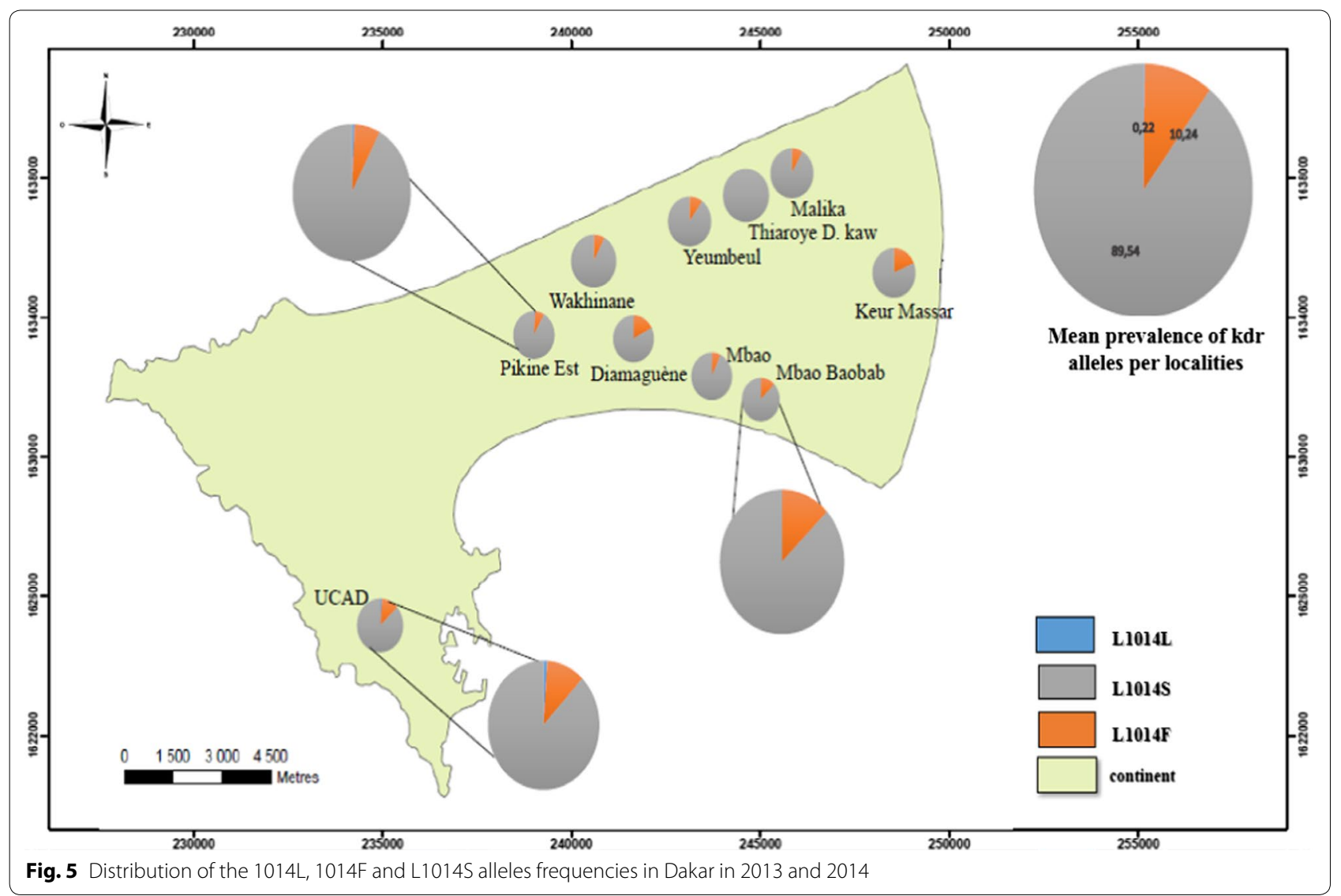

gene [37], which was not investigated during this study. However, there is an urgent need to investigate all potential insecticide resistance mechanisms for a suitable insecticide management system.

During this study, a proportion of mosquitoes did not harbour the $k d r$ alleles while the populations were fully resistant, suggesting the existence of other resistance mechanisms. Further analysis revealed the involvement of metabolic resistance mechanisms implying GST and CYP450 detoxification genes families. Indeed, the susceptibility of studied populations to DDT and permethrin was fully restored following a pre-exposure to the $\mathrm{PBO}$ or EA. Similar results have been previously reported in different places in Dakar, including Fass and Colobane [38], in Benin [39, 40] and in Cameroon [41]. However, data presented in both studies are limited and need to be completed and updated to fully characterize the resistance of An. arabiensis populations to insecticide and underlying mechanisms.

\section{Conclusions}

This study summarizes the insecticide resistance status and underlying mechanisms in An. arabiensis populations in the flooded areas of the Dakar suburbs. Noteworthily, it revealed the contribution of both target-site and metabolic resistance mechanisms in the study populations. These data, although preliminary, stress the need for close monitoring of the urban An. arabiensis populations for the implementation of a suitable insecticide resistance management system to preserve core insecticide-based vector control tools in this flooded area.

\section{Authors' contributions}

DAK, GOK and KA undertook the field and laboratory work. DAK, NEA and GOK analysed the results. DAK and NEA drafted the manuscript. KL and FO designed the study. NEA, DA, SB, DSM and SMD reviewed the manuscript. All authors read and approved the final manuscript.

\section{Author details}

${ }^{1}$ Laboratoire d'Ecologie Vectorielle et Parasitaire, Université Cheikh Anta Diop, Dakar, Senegal. ${ }^{2}$ Aix Marseille Univ, IRD, APHM, MEPHI, IHU-Méditerranée Infection, Marseille, France. ${ }^{3}$ Abt Associates, PMI Africa Indoor Residual Spraying Project, Dakar, Senegal.

\section{Acknowledgements}

This study was carried out with the support of the PMI project in Senegal which gives all reagents and equipment. 


\section{Competing interests}

The authors declare that they have no competing interests.

\section{Availability of data and materials}

The datasets generated and/or analysed during the current study are available from the corresponding author on reasonable request.

\section{Ethics approval and consent to participate}

Not applicable.

\section{Publisher's Note}

Springer Nature remains neutral with regard to jurisdictional claims in published maps and institutional affiliations.

\section{Received: 15 November 2017 Accepted: 9 March 2018}

Published online: 15 March 2018

\section{References}

1. WHO. Global plan for insecticide management. Geneva: World Health Organization; 2012

2. Diedhiou SM, Niang EA, Doucoure S, Samb B, Konate A, Cissokho S, et al. Distribution and characterization of anopheline larval habitats in flooded areas of the Dakar suburbs. J Parasitol Vector Biol. 2016;8:61-73.

3. Diédhiou SM, Konaté L, Doucouré S, Samb B, Niang EA, Sy O, et al. Efficacité de trois larvicides d'origine biologique et d'un régulateur de croissance contre Anopheles arabiensis au Sénégal. Bull Soc Path Exot. 2017:110:102-15.

4. Machault V, Gadiaga L, Vignolles C, Jarjaval F, Bouzid S, Sokhna C, et al. Highly focused anopheline breeding sites and malaria transmission in Dakar. Malar J. 2009;8:138.

5. Machault V, Vignolles C, Pages F, Gadiaga L, Gaye A, Sokhna C, et al. Spatial heterogeneity and temporal evolution of malaria transmission risk in Dakar, Senegal, according to remotely sensed environmental data. Malar J. 2010;9:252.

6. Gadiaga L, Machault V, Pagès F, Gaye A, Jarjaval F, Godefroy L, et al. Conditions of malaria transmission in Dakar from 2007 to 2010. Malar J. 2011;10:312.

7. Ramsammy L. We can end malaria by 2030 - we have an obligation to. 2017. https://www.linkedin.com/pulse/we-can-end-malaria-2030-haveobligation-leslie-ramsammy. Accessed 1 Oct 2017.

8. PNLP. Plan stratégique national de lutte contre le paludisme au Sénégal 2016-2020. Programme National de Lutte contre le Paludisme (PNLP) Ministère de la Santé et de Prévention Médicale. 2015. p. 171.

9. The President's Malaria Initiative Eleventh Report to Congress. 2017. https ://www.pmi.gov/docs/default-source/default-document-library/pmireports/2017-pmi-eleventh-annual-report.pdf. Accessed 7 Oct 2017.

10. Faye $\mathrm{O}$, Konate $L$, Diop A. Profil entomologique du paludisme au Sénégal. Ministére la Santé la Prévention Médicale. 2011. p. 39.

11. Agence Nationale de l'Aviation Civile et de la Météorologie (ANACIM). Note sur le bilan de l'hivernage 2015. 2015. http://www.anacim.sn/oldsi te/IMG/pdf/-185.pdf. Accessed 3 Oct 2017.

12. ANSD. Recencement Général de la Population et de l'Habitat, de I'Agriculture et de l'Elevage RGPHAE 2013. Agence Nationale de la Statistique et de la Démographie (ANSD), Ministère de l'Economie et des Finances. 2014. p. 418

13. MR4. Method in Anopheles research. 4th ed. New York: CABI Publishing; 2014.

14. WHO. Test procedures for insecticide resistance monitoring in malaria vector mosquitoes. Geneva: World Health Organization; 2013.

15. Brogdon WG, McAllister JC. Simplification of adult mosquito bioassays through use of time-mortality determinations in glass bottles. J Am Mosa Control Assoc. 1998:14:159-64.

16. Wilkins EE, Howell PI, Benedict MQ. IMP PCR primers detect single nucleotide polymorphisms for Anopheles gambiae species identification, Mopti and Savanna rDNA types, and resistance to dieldrin in Anopheles arabiensis. Malar J. 2006:7:1-7.

17. Huynh LY, Sandve SR, Hannan LM, Van Ert M, Gimnig JE. Fitness costs of pyrethroidinsecticide resistance in Anopheles gambiae. Annual Meeting of the Society for the Study of Evolution, Christchurch, New Zealand. 2007.

18. R Core Team. R: A language and environment for statistical computing. R Foundation for Statistical Computing, Vienna, Austria. 2016. http:// www.R-project.org/.

19. Machault V, Vignolles C, Pagès F, Gadiaga L, Tourre YM, Gaye A, et al. Risk mapping of Anopheles gambiae s.l. densities using remotely-rensed environmental and meteorological data in an urban area: Dakar, Senegal. PLOS ONE. 2012;7:e50674.

20. Pagès F, Texier G, Pradines B, Gadiaga L, Machault V, Jarjaval F, Penhoat K, Berger F, Trape JF, Rogier C, Sokhna C. Malaria transmission in Dakar: a two-year survey. Malar J. 2008;7(1):178

21. Robert V, Awono-Ambene HP, Thioulouse J. Ecology of larval mosquitoes, with special reference to Anopheles arabiensis (Diptera: Culcidae) in market-garden wells in urban Dakar, Senegal. J Med Entomol. 1998;35:948-55.

22. Vercruysse J, Jancloes M. Etude entomologique sur la transmission du paludisme humain dans la zone urbaine de Pikine (Sénégal). Cah ORSTOM Série Entomol Méd Parasitol. 1981;19:165-78.

23. Faye O, Gaye O, Diallo S. Evaluation de la sensibilité d'Anopheles gambiae s.l au Fénitrothion au Malathion et au DDT au Sénégal. Dakar Médical. 1991;36:170-7.

24. Cissé I, Fall ST, Badiane M, Diop Y, Diouf A. Horticulture et usage des pesticides dans la zone des Niayes au Sénégal, document de travail Ecocité n8. ISRA/LNERV, EISMV, LACT/Faculté de Médecine Pharmacie/UCAD. 2006. p. 14

25. Niang EHA, Konaté L, Diallo M, Faye O, Dia I. Patterns of insecticide resistance and knock down resistance ( $k d r)$ in malaria vectors An. arabiensis, An. coluzzii and An. gambiae from sympatric areas in Senegal. Parasit Vectors. 2016;9:71.

26. Faye O, Gaye O, Fontenille D, Hebrard G, Konate L, Sy N, et al. La sécheresse et la baisse du paludisme dans les Niayes du Sénégal. Cahier Santé 1995:5:299-305.

27. Diabate A, Baldet T, Chandre F, Akogbeto M, Guiguemde TR, Darriet F, et al. The role of agricultural use of insecticides in resistance to pyrethroids in Anopheles gambiae s.l. in Burkina Faso. Am J Trop Med Hyg. 2002;67:617-22.

28. Padonou G, Sezonlin M, Ossé R, Aizoun N, Oké-Agbo F, Oussou O, et al. Impact of three years of large scale indoor residual spraying (IRS) and insecticide treated nets (ITNs) interventions on insecticide resistance in Anopheles gambiae s.l. in Benin. Parasit Vectors. 2012;5:72.

29. Soderlund DM, Knipple DC. The molecular biology of knockdown resistance to pyrethroid insecticides. Insect Biochem Mol Biol. 2003;33:563-77.

30. Lynd A, Weetman D, Barbosa S, Yawson AE, Mitchell S, Pinto J, et al. Field, genetic, and modeling approaches show strong positive selection acting upon an insecticide resistance mutation in Anopheles gambiae s.s. Mol Biol Evol. 2010;27:1117-25.

31. Dabiré RK, Namountougou M, Diabaté A, Soma DD, Bado J, Toé HK, et al. Distribution and frequency of kdr mutations within Anopheles gambiae s.l. populations and first report of the ace.1 G119S mutation in Anopheles arabiensis from Burkina Faso (West Africa). PLoS ONE. 2014;9:e101484

32. Kabula B, Kisinza W, Tungu P, Ndege C, Batengana B, Kollo D, et al. Cooccurrence and distribution of East (L1014S) and West (L1014F) African knock-down resistance in Anopheles gambiae sensu lato population of Tanzania. Trop Med Int Health. 2014;19:331-41.

33. Etang J, Fondjo E, Chandre F, Morlais I, Brengues C, Nwane P, et al. First report of knockdown mutations in the malaria vector Anopheles gambiae from Cameroon. Am J Trop Med Hyg. 2006;74:795-7.

34. Nwane P, Etang J, Chouaïbou M, Toto JC, Mimpfoundi R, Simard F. Kdrbased insecticide resistance in Anopheles gambiae ss populations in Cameroon: spread of the L1014F and L1014S mutations. BMC Res Notes. 2011;4(1):463

35. Pinto J, Lynd A, Elissa N, Donnelly MJ, Costa C. Co-occurrence of East and West African kdr mutations suggests high levels of resistance to pyrethroid insecticides in Anopheles gambiae from Libreville, Gabon. Med Vet Entomol. 2006:3652600:27-32.

36. Verhaeghen K, Van Bortel W, Roelants P, Backeljau T, Coosemans M. Detec tion of the East and West African kdr mutation in Anopheles gambiae and Anopheles arabiensis from Uganda using a new assay based on FRET/Melt Curve analysis. Malar J. 2006;5:16. 
37. Weill M, Lutfalla G, Mogensen K, Chandre F, Berthomieu A, Berticat C, et al. Insecticide resistance in mosquito vectors. Nature. 2003;423:137-8.

38. Thiaw $\mathrm{O}$. Evaluation de la sensibilité aux insecticides par la technique des tests de bio-essais en bouteille du CDC et détermination des mécanismes de résistance chez An. gambiae s.l. dans la ville de Dakar, Sénégal. Université Cheikh Anta Diop; 2014.

39. Djègbè I, Boussari $O$, Sidick $A$, Martin $T$, Ranson $H$, Chandre $F$, et al. Dynamics of insecticide resistance in malaria vectors in Benin: first evidence of the presence of L1014S kdr mutation in Anopheles gambiae from West Africa. Malar J. 2011;10:261.
40. Aïzoun N, Aïkpon R, Padonou GG, Oussou O, Oké-Agbo F, Gnanguenon V, et al. Mixed-function oxidases and esterases associated with permethrin, deltamethrin and bendiocarb resistance in Anopheles gambiae s.l. in the south-north transect Benin, West Africa. Parasit Vectors. 2013;6:223.

41. Nwane P, Etang J, Chouaïbou M, Toto JC, Koffi A, Mimpfoundi R, et al. Multiple insecticide resistance mechanisms in Anopheles gambiae s.l. populations from Cameroon, Central Africa. Parasit Vectors. 2013;6:41.

\section{Submit your next manuscript to BioMed Central and we will help you at every step:}

- We accept pre-submission inquiries

- Our selector tool helps you to find the most relevant journal

- We provide round the clock customer support

- Convenient online submission

- Thorough peer review

- Inclusion in PubMed and all major indexing services

- Maximum visibility for your research

Submit your manuscript at

www.biomedcentral com/submit 